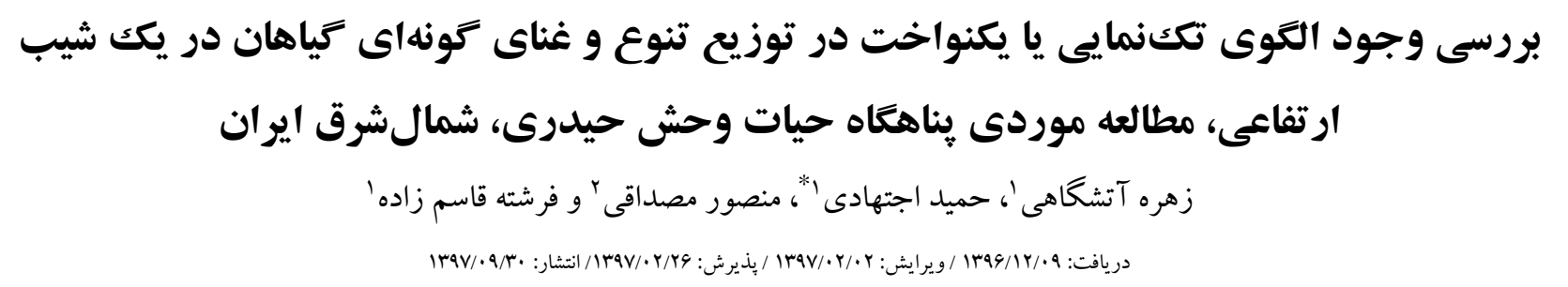

$$
\begin{aligned}
& \text { اخروه زيست شناسى، دانشكده علوم، دانشگاه فردوسى مشهد، مشهد، ايران }
\end{aligned}
$$

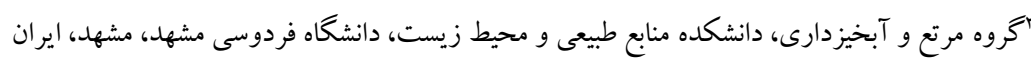

$$
\begin{aligned}
& \text { hejtehadi@um.ac.ir مسئول مكاتبات }
\end{aligned}
$$

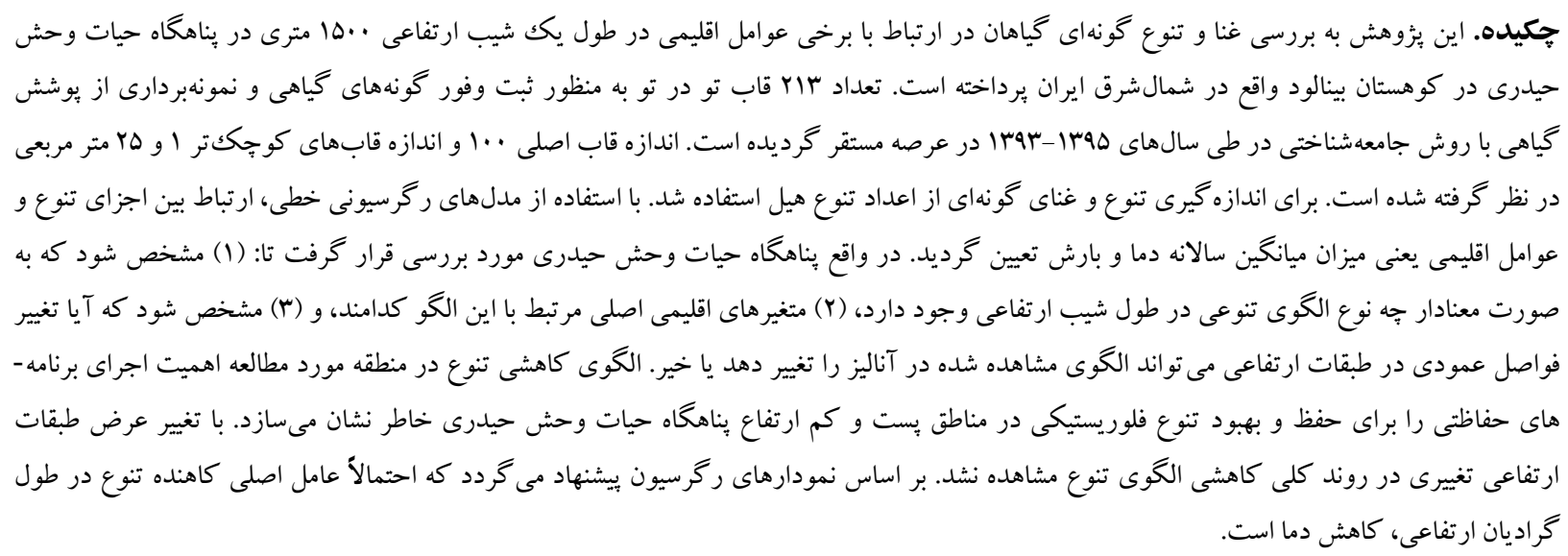$$
\text { وازههاى كليدى. اعداد هيل، الكوى توزيع، بينالود، تنوع زيستى، خراسان رضوى }
$$

\title{
The existence of a unimodal or monotonic pattern in species richness and diversity along an elevational gradient: a case study in Heydari Wildlife Refuge, NE Iran Zohreh Atashgahi ${ }^{1}$, Hamid Ejtehadi ${ }^{1, *}$, Mansoor Mesdaghi ${ }^{2}$ \& Fereshteh Ghassemzadeh ${ }^{1}$ Received: 28.02.2018 / Revised: 22.04.2018 / Accepted: 16.05.2018/ published:21.12.2018
}

\begin{abstract}
${ }^{1}$ Department of Biology, Faculty of Sciences, Ferdowsi University of Mashhad, Mashhad, Iran ${ }^{2}$ Department of Range and Watershed Management, Faculty of Natural Resources and Environment, Ferdowsi University of Mashhad, Mashhad, Iran

*Correspondent author: hejtehadi@um.ac.ir
\end{abstract}

\begin{abstract}
This article presents an analysis of plant species richness and diversity, concerning some climatic variables along a 1500-m elevation gradient on the Binalood Mountain in Heydari Wildlife Refuge (HWR), northeastern Iran. Two hundred and thirteen nested-sampling quadrats were established and the abundance of the plants was recorded. Vegetation sampling was carried out from 2014 till 2016, following the phytosociological procedure. The size of the main plots was $100 \mathrm{~m}^{2}$ with subplots of 1 and $25 \mathrm{~m}^{2}$ inside. Hill numbers were used to assess the species richness and diversity. The relationships between species richness, diversity and environmental variables, i.e., temperature and precipitation, were obtained by using simple linear regression models. HWR was studied in order to: (1) examine the significant diversity pattern existing along the elevational gradient; (2) determine the main climatic variables associated with this pattern; (3) to establish whether changing the width of elevation classes modified the pattern or not. The monotonic and reductional diversity pattern in the study area indicates the importance of performing conservation programs for the maintainance and improvement of floristic diversity on accessible lowlands of the HWR. Modifying the width of elevation classes did not alter the general trend of the reductional diversity pattern. The regression curves suggested that differences in plant diversity along elevational gradients may be mainly influenced by temperature.
\end{abstract}

Keywords. Binalood, biodiversity, distribution pattern, hill numbers, Khorassan-Razavi 


\section{INTRODUCTION}

In many parts of the world, changes in land use, habitat fragmentation, and environmental stress have been intensified and often led to reduced biodiversity in natural ecosystems (Wilsey \& Potvin, 2000). These changes are increasingly challenging the main objectives of ecosystem management, i.e., providing ecosystem services sustainable to the society and maintaining the biological diversity of ecosystems. Assessment of the spatial patterns of biodiversity, especially in relation to latitude and altitude (elevation), is one of the most challenging objectives in ecology. Latitudinal gradients in species richness and diversity are highly investigated and documented (Rahbek, 1997, 2005; Whittaker et al., 2001; Willig et al., 2003; Rohde, 1992; Spehn \& Korner, 2010). Besides, research on biodiversity patterns, especially on elevational patterns at mountains, has been notably increasing all over the world (e.g. Spehn \& Korner, 2010; Guo et al., 2013; Nogué et al., 2013). The tendency to study mountains is observed more often in extensive elevational gradients and diverse vegetation zones to examine diversity patterns (Underwood et al., 2009). Biogeographists such as Lomolino (2001) mentioned specific environmental and biogeographical factors responsible for different patterns of diversity distribution along latitudinal and altitudinal gradients. Comprehensive literature review by Rahbek (2005) showed the dominance of two main patterns of diversity-elevation: (1) unimodal pattern of species richness and diversity in elevational gradients (see Sánchez-González \& López-Mata, 2005; Cardelús et al., 2006; Watkins et al., 2006; Zhang et al., 2009; Aynekulu et al., 2012; Guo et al., 2013); (2) monotonic decline in biodiversity with an ascending in elevation (e.g. Smith, 2015; Vázquez \& Givnish, 1998; Stevens, 1992 and references therein) that is coincident with Rapoport's elevation rule (Rapoport, 1982; Stevens, 1992) that proposes species found at higher elevations can tolerate a broad range of climatic conditions, leading to a broad elevation range. Species occurring at lower elevations are adapted to more specific temperature and rainfall conditions so they have narrow climatic tolerances and hence a smaller range, resulting in more species and more diversity (Bhattarai \& Vetaas, 2006). Sometimes other patterns (e.g. Eisenlohr et al., 2013) are also observed in the mountains. Therefore, it is necessary to continued research on the diversityelevation patterns on the basis of common diversity indices.

Diversity has two components: species richness, or the number of species in a given area, and evenness, or how well-distributed abundance or biomass is among species within a community (Magurran, 1988; Ejtehadi et al., 2009). There are numerous diversity indices introduced by scientists that well declare the variation of life. According to Morris et al. (2014), data mining for the identification of the index producing the most significant results should be avoided. Each diversity index has its own limitations. Hill numbers, or the effective number of species, are a mathematically integrated group of diversity indices (differing among themselves only by an exponent q) which overcome many of these limitations. They are increasingly used to illustrate the diversity of an assemblage (Chao et al., 2014). Despite the nomination, Hill numbers were first used in ecology by MacArthur (1965), developed by Hill (1973) and recently introduced again by Chao et al. (2014). For distinct advantages of Hill numbers, compared with other diversity indices, see Chao et al. (2014). Unequal sample size in different elevation sites, as in our case, recommends using Hill numbers, or the effective number of species, to assess the species richness and diversity at the arid grasslands.

Grasslands, covering as much as $25 \%$ of the Earth's lands, have provided considerable grazing fileds for both wild and domestic animals. Grasslands usually occur in hot summer temperatures and low precipitation. The steppe grasslands with limited distribution receive only 25 $50 \mathrm{~cm}$ of rainfall each year, occurring in Central and Eastern Europe, Northern Eurasia, Western North America (Bahadur et al., 2015), and also in the mountains of the Mideast. Despite the importance of the direct and indirect benefits provided by these grasslands, few studies have covered the full elevation gradient to precisely describe existing variations in their structure and composition. Nevertheless, patterns in species richness and diversity and their relationship with soil and climate factors are unknown in the steppe grasslands. Heydari wildlife refuge (HWR), located in the Binalood mountains, Northeastern Iran in the Mideast, is dominated by steppe-cushion grasslands with a range of 1500-meter elevation gradient. The occurrence of xerophytic plant species and communities with heterogeneous distribution, human disturbances, agriculture and livestock grazing in some parts of the HWR and other drivers of environmental changes made it a suitable area for investigating diversity-elevation pattern. The study attempted to answer the following questions: Does species richness and diversity vary significantly with elevation change along the gradient studied? Do variations along the elevation gradient follow a 
monotonic, unimodal or another pattern? What are the main environmental variables associated with these variations? And does changing the width of elevation classes modify the pattern? The answers to these questions seek to contribute knowledge on species richness and diversity patterns in a semiarid wildlife refuge.

\section{MATERIALS AND METHODS}

\section{Study area and its vegetation}

The study was conducted at the Heydari wildlife refuge (HWR), in the Binalood Mountains, Khorassan-Razavi Province, NE Iran $\left(36^{\circ} 40^{\prime} \mathrm{N}, 58^{\circ}\right.$ 37'E, 1400-2900 m.a.s.l.) (Fig. 1). The wildlife refuge, with approximately 46350 ha., is characterized by an arid Irano-Turanian climate, based on Djamali et al. (2012). Mean annual temperature is $12.7^{\circ} \mathrm{C}$ and mean annual rainfall is $315 \mathrm{~mm}$, most of which falls in autumn-winter (IRIMO, 2016: Quchan Station, 1994-2014 period). HWR, the largest wildlife refuge in the NE Iran, with 588 vascular plant species and subspecies, is covered by thorn-cushion plants mainly as different combinations of Acantholimon spp., Astragalus spp., and Acanthophyllum spp., and in the lower elevations, Artemisia and Artemisia-Astragalus steppes are dominated. The woodlands of Juniperus polycarpos Koch var. turcomanica (Fedtschenko) Adams occur as small patches in the uplands of the HWR (for more information on the floristic composition of the HWR refers to Atashgahi et al., 2018).

\section{Methodology}

Field surveys were conducted over three growth periods (2014-2016) during which 213 partial random nested quadrats (Fig. 2) were placed in different habitats along the elevational gradient $(1400$ to $2900 \mathrm{~m})$. The abundance of vascular plants, along with the geographical position, elevation, aspect, and slope, was recorded in the field. The abundance data were managed and subjected to diversity indices by the software $\mathrm{R}$ (2016), package: inext (Chao et al., 2014; Hsieh et al., 2016). Although mountainous regions describing the natural layering of ecosystems occur at distinct altitudes (Daubenmire, 1943), it is difficult to determine altitudinal zones in the HWR. Such difficulties may have been due in part to the fact that cushion-steppe vegetation of HWR, despite shifting in floristic composition, is so homogenous and the available ecological surveys are so limited in this area. In this study, we specified altitudinal zones subjectively to see the effect of elevation class' width on the pattern of diversity along the elevation. Hill numbers $\left(\mathrm{N}_{0}, \mathrm{~N}_{1}\right.$, and $\left.\mathrm{N}_{2}\right)$ were calculated at $95 \%$ confidence level in the four assigned elevation classes: (1) twelve $100 \mathrm{~m}$ elevation intervals (vertical elevation band), (2) six 200 m elevation intervals, (3) three $500 \mathrm{~m}$ elevation intervals, and (4) three unequal ones in which the range of three interval classes are 400,600, $500 \mathrm{~m}$.
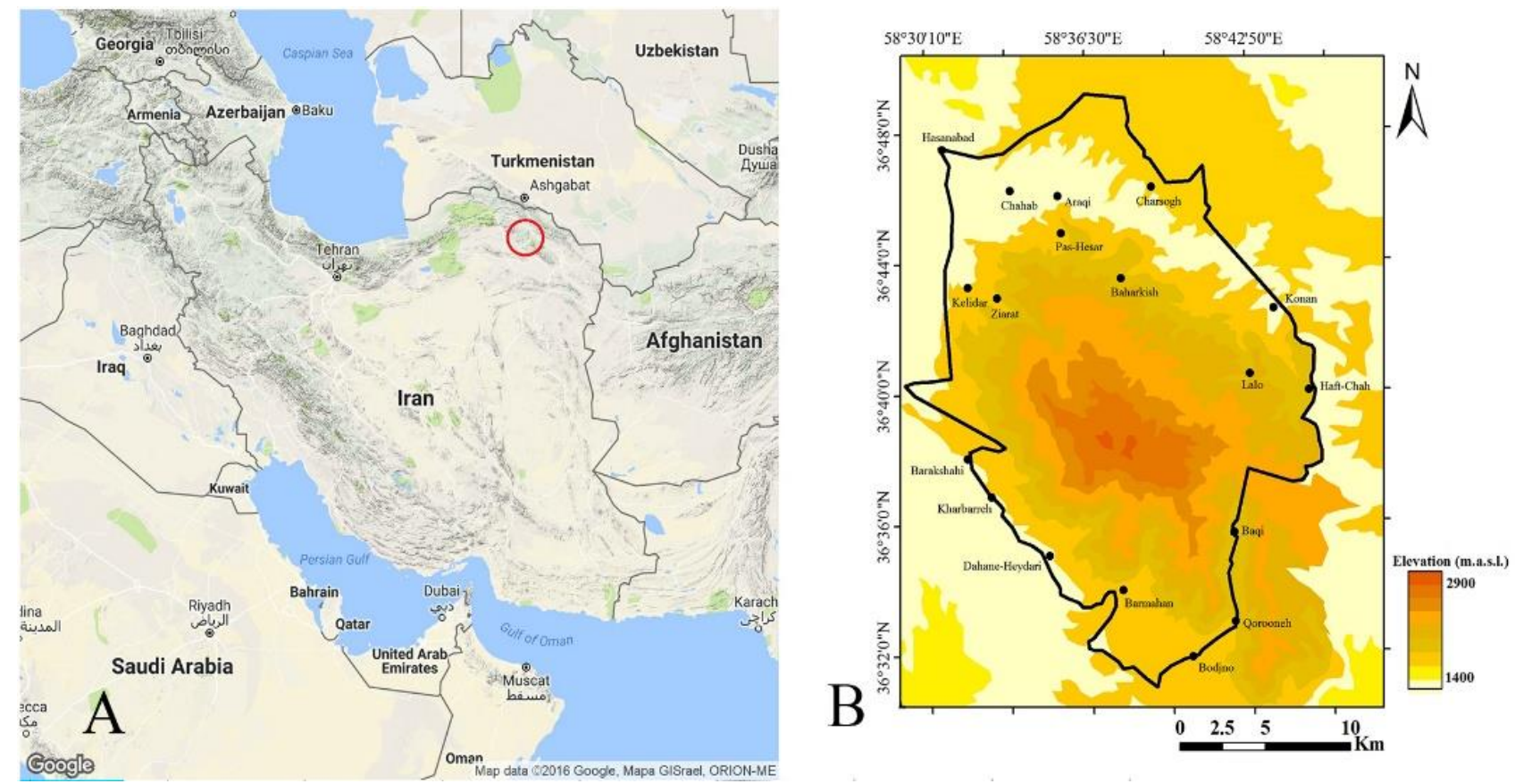

Fig. 1. A: The map of Iran in the Middle East (prepared in R, 2016), the inset shows the location of the HWR, B: Topographic map of the HWR (after Atashgahi et al., 2018), showing the summer villages. 


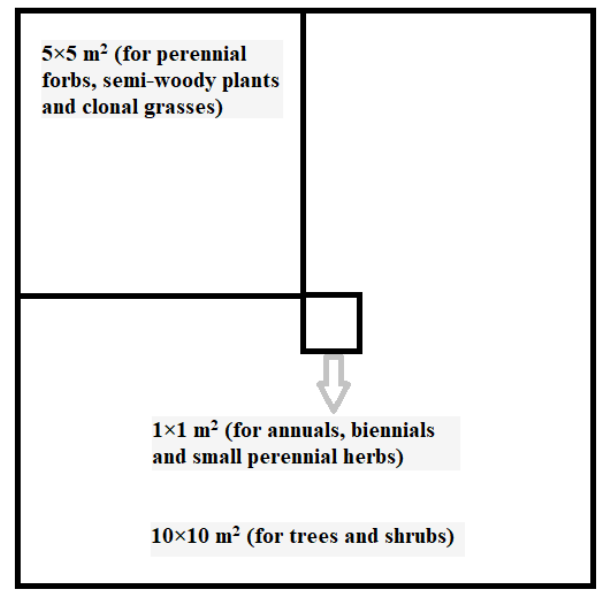

Fig. 2. The frame of nested quadrats established in the study area.

Mean annual temperature $\left({ }^{\circ} \mathrm{C}\right)$ and precipitation $(\mathrm{mm})$ for each sampling unit were extracted from Openmodeller (Muñoz et al., 2011) using climatological layers of southwest Asia (Hijmans et al., 2005). Linear regressions between elevation and temperature/precipitation were developed in $\mathrm{R}$ (2016) (Fig. 4).

\section{RESULTS AND DISCUSSION}

Based on Hill numbers $\left(\mathrm{N}_{0}, \mathrm{~N}_{1}\right.$, and $\left.\mathrm{N}_{2}\right)$, species richness and diversity decline monotonically toward the highest elevation at the HWR. On the other hand, low elevations displayed more plant diversity than high mountains (Fig. 3). The trend was almost the same in all categories of elevational classifications, i.e., $100 \mathrm{~m}$ (Fig. 3: A1-A3), $200 \mathrm{~m}$ (Fig. 3: B1-B3), $500 \mathrm{~m}$ (Fig. 3: $\mathrm{C} 1-\mathrm{C} 3$ ), and unequal elevational bands (Fig. 3: D1-D3). Although adjacent classes didn't show a significant difference in Hill numbers when the width of a class is small (i.e. 100 or 200 m, Fig. 3: A1-A3 or B1-B3), increasing the interval of elevational classes revealed significant differences resulting in discriminating vegetation on the basis of diversity.

Mean annual precipitation and temperature were significantly correlated with elevation depicting a linear relationship (elevation vs. precipitation: $r^{2}=$ 0.99; elevation vs. temperature: $r^{2}=0.95 P<$ 0.0001 , see Fig. 4). The diversity of many taxonomic groups, including plants, decreases while moving from low to high latitudes (Gaston, 2000). Most major taxonomic groups are more diverse in tropical than in temperate regions, at low elevations than higher elevations, and in forests than deserts. Thus, relationships between species richness and environmental factors have been found to be associated with latitudinal and elevational gradients (Rohde, 1992).
At great elevational ranges a hump-shaped pattern of diversity usually dominates: for instance, at a $3300 \mathrm{~m}$ elevational gradient in the Nepalese Himalaya (Bhattarai \& Vetaas, 2006), a 2700m gradient in the Hubei Province, China (Hua, 2004), and a $5900 \mathrm{~m}$ gradient in the Manang, Nepal (Subedi et al., 2015). However, it may not be a constant rule as in the case of greater elevational extents with a monotonic pattern in Costa Rica, about 3000m (Holdridge et al., 1971). The humpshaped patterns may also occur at short elevational gradients (e.g. in Tennessee, $1200 \mathrm{~m}$ (Whittaker, 1956), in Hyrcanian forests, Iran, $1300 \mathrm{~m}$ (Atashgahi et al., 2015)). On the basis of the study on 443 elevational gradients all over the world, Guo et al. (2013) stated that mountains with greater elevational ranges and taxonomic groups that are more inclusive show proportionately more unimodal patterns in diversity whereas other ranges and taxa show highly variable gradients.

In all regions, lower elevations are most altered by threats such as human population density, agricultural activities and urbanization (Underwood et al., 2009; Guo et al., 2013). It is important to take into account that little information exists on the elevational distribution of plants in the HWR and its adjacent areas. Considering the location of several villages, mostly under cultivation and next to the lower boundaries of the HWR, one may consider that extending the sampling out of the borders of HWR may reveal human disturbances on decreasing diversity. Thus, the monotonic pattern of diversity (Fig. 3) may shift to a unimodal one. Undoubtedly, according to Rahbek (2005), the scale may affect patterns of diversity. Although more studies show a hump-shaped pattern at the regional elevation scale, this pattern may completely alter with scale. Therefore, the type of the pattern varies with the length of the gradient surveyed. 

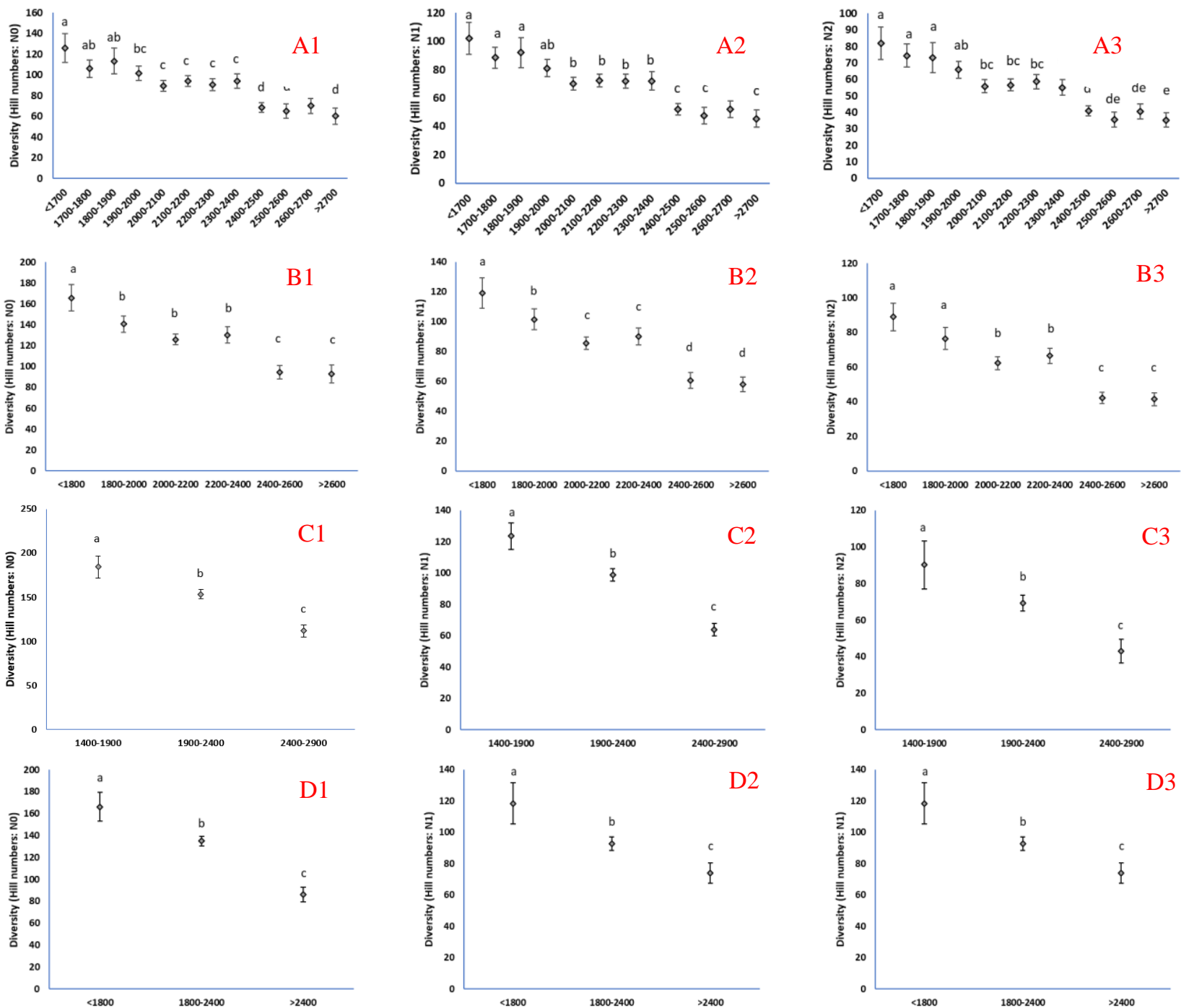

Fig. 3. Trends in changes of species diversity along an elevation gradient in the HWR based on Hill numbers $\left(\mathrm{N}_{0}, \mathrm{~N}_{1}\right.$, and $\mathrm{N}_{2}$ ). Width of elevational band is $100 \mathrm{~m}$ (A1-A3), $200 \mathrm{~m}$ (B1-B3), $500 \mathrm{~m}$ (C1-C3), and unequal (D1-D3). Narrow bars indicate $95 \%$ confidence intervals. No significant differences are indicated by similar letters on each graph. The species diversity tends to decrease when elevation is increased. As obvious, the same trend is observed at all elevation intervals.

As a consequence of the short scale of extent, the altitudinal pattern in the HWR seems not to have a unimodal shape. The majority of the lowlands $(<1800 \mathrm{~m})$ with most species richness in the HWR (Fig. 3) are located in the north and northwestern parts of the area (Fig. 2). Agricultural activities are performed in the fertile lowlands outside HWR and extend into the flat areas and valleys of HWR. It is expected that the agricultural activities make the diversity reduced. In spite of this, low mountains and foothills surrounded by the agricultural lands in HWR are protected by farmers and act as islands which preserve unintentionally the natural vegetation from grazing and other human disturbances. This indirect protection, along with a suitable temperature, promotes plant growth conditions and maintains diversity at a high level. The elevational rule can be explained as being the results of differences in the breadth of climatic conditions that organisms experience along the geographical gradients (Stevens, 1992). The decreasing area of higher elevational bands and/or the isolation of mountaintops, in comparison with the valleys, may account for the decrease of the community richness with the increase of the elevation. Thus, the low species richness of high elevations may reflect the low rates of invasion and/or the high extinction rates of populations that colonize them (Stevens, 1992). At the highlands of HWR, having a cold temperature, the local reproductive rate of many species often falls below their mortality rate. 

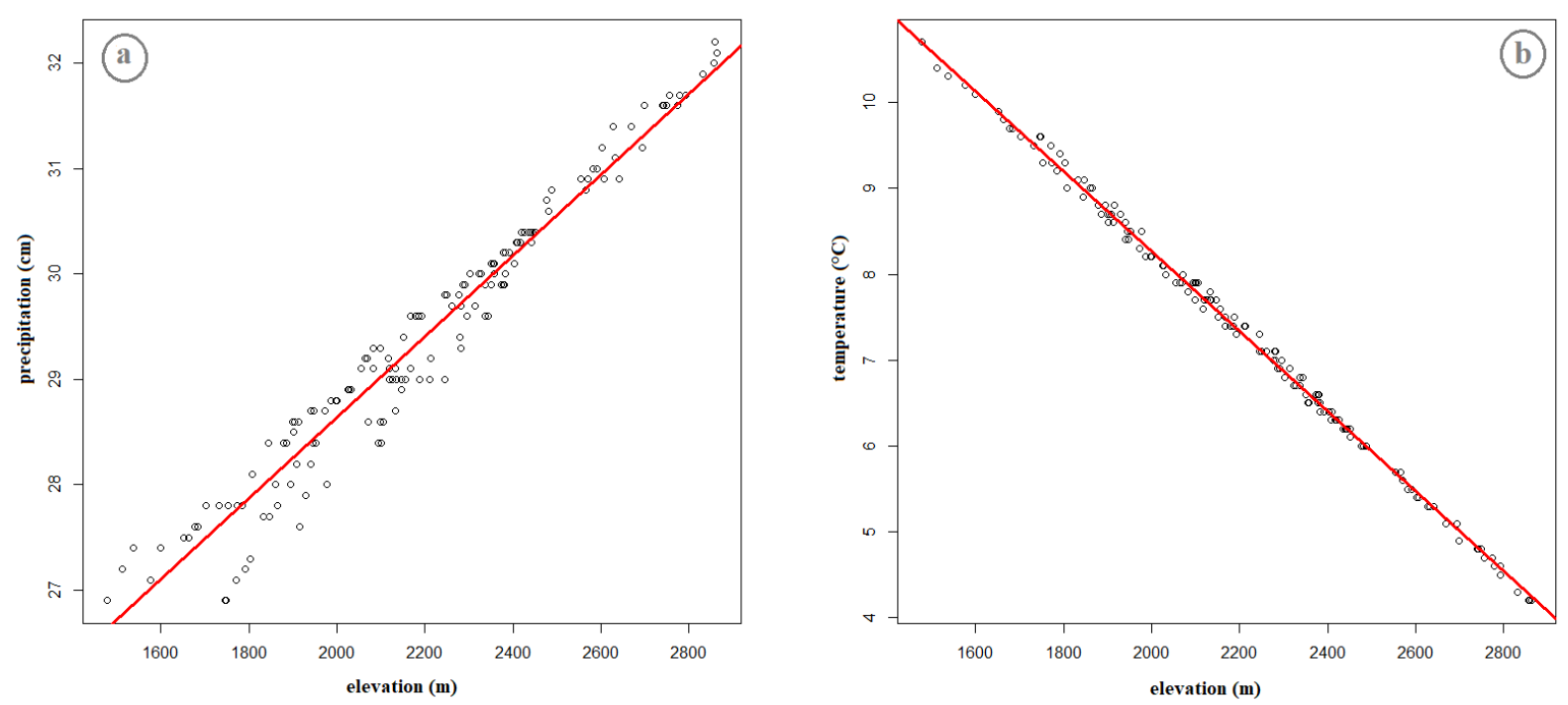

Fig. 4. Linear regression of elevation (a) vs. mean annual precipitation (R-squared $=0.9536, p<0.0001)$, (b) vs. mean annual temperature (R-squared $=0.9971, \mathrm{p}<0.0001$ ) in the HWR. Each point represents a single $30^{\prime \prime} \times 30^{\prime \prime}$ latitudelongitude gird cell $(\mathrm{n}=213)$ that contains the sampling units.

McCain \& Grytnes (2010) have described biotic and abiotic factors that vary with elevation and can be important determinants of species richness. Local climatic conditions, such as prevailing winds, local temperature and precipitation regimes, may alter the pattern of species richness. In addition to local climatic conditions, humidity, soil composition, and solar radiation are important factors in determining altitudinal zones, which consequently support different vegetation types and animal species (Daubenmire 1943; Stevens, 1992). Several factors change predictably with the increase of elevation; the most obvious of which, is the general linear decrease in temperature. The most common elevational pattern is the increase of precipitation with the increase of elevation. This pattern predominates mountains at temperate latitudes and arid regions regardless of the latitude (McCain \& Grytnes, 2010). Several scientists use the climatic factors to explain diversity pattern along the elevation gradients (Bhattarai \& Vetaas, 2003; Watkins et al., 2006; McCain \& Grytnes, 2010; Ribeiro, 2014). In the highlands of HWR, predominant dry-severe winds in the evenings may lead to the decrease of diversity, in addition to cold temperature and short growing season. In general, temperature (Fig. 3b) may be regarded as the main determinant of the elevational factors that manage the species richness pattern in HWR. This pattern of decreasing diversity is the consequence of the decrease of temperature and the increase of elevation. HWR, as an important ecosystem in the Northeast of Iran, is affected by such major negative impacts as the construction of roads, the conversion into agricultural lands, grazing, mining, over-collection of the medicinal plants and the introduction of exotics.

\section{ACKNOWLEDGEMENT}

We wish to thank the office of the Vice President for Research and Technology, Ferdowsi University of Mashhad, for financial support (Grant number: 33474). We also wish to acknowledge the scientific members of the Herbarium of Ferdowsi University of Mashhad for the identification of several critical taxa.

\section{REFERENCES}

Atashgahi, Z., Ejtehadi, H. and Zare, H. 2015. Plant species diversity in relation to topography in the east of Dodangeh forests, Mazandaran province, Iran. - J. of plant res. Iranian J. Biol. 28: 1-11.

Atashgahi, Z., Ejtehadi, H., Mesdaghi, M. and Ghassemzadeh, F. 2018. Plant diversity of the Heydari Wildlife Refuge in northeastern Iran, with a checklist of vascular plants. - Phytotaxa 340: 101127.

Aynekulu, E., Aerts, R., Moonen, P., Denich, M., Gebrehiwot, K., Vågen, T.-G., Mekuria, W. and Boehmer, H.J. 2012. Altitudinal variation and conservation priorities of vegetation along the Great Rift Valley escarpment, northern Ethiopia, Biodivers. Conserv. 21: 2691-2707.

Bahadur, B., Pullaiah, T. and Krishnamurthy, K.V. 2015. Plant Biology and Biotechnology: Volume I: 
Plant Diversity, Organization, Function and Improvement. - Springer India. 827 pp.

Bhattarai, K.R. and Vetaas, O.R. 2003. Variation in plant species richness of different life forms along a subtropical elevation gradient in the Himalayas, east Nepal. - Glob. Ecol. And Biogeogr. 12: 327-340.

Bhattarai, K.R. and Vetaas, O.R. 2006. Can Rapoport's rule explain tree species richness along the Himalayan elevation gradient, Nepal? - Diversity Distrib. 12: 373-378.

Cardelús, C.L., Colwell, R.K. and Watkins, J.E.J. 2006. Vascular epiphyte distribution patterns: explaining the mid-elevation richness peak. - J. Ecol. 94: 144-156.

Chao, A., Gotelli, N.J., Hsieh, T.C., Sander, E.L., Ma, K.H., Colwell, R.K. and Ellison, A.M. 2014. Rarefaction and extrapolation with Hill numbers: a framework for sampling and estimation in species diversity studies. - Ecol. Monogr. 84: 45-67

Daubenmire, R.F. 1943. Vegetational Zonation in the Rocky Mountains. - Bot. Rev. 9: 325-393.

Djamali, M., Brewer, S., Breckle, S.W. and Jackson, S.T. 2012. Climatic determinism in phytogeographic regionalization: A test from the Irano-Turanian region, SW and Central Asia. - Flora 207: 237-249.

Eisenlohr, P.V., Alves, L.F., Bernacci, L.C., Padgurschi, M.C.G., Torres, R.B., Prata, E.M.B., dos Santos, F.A.M., Assis, M.A., Ramos, El., Rochelle, A.L.C., Martins, F.R., Campos, M.C.R., Pedroni, F., Sanchez, M., Pereira, L.S., Vieira, S.A., Gomes, J.A.M.A., Tamashiro, J.Y., Scaranello, M.A.S., Caron, C.J. and Joly, C.A. 2013. Disturbances, elevation, topography and spatial proximity drive vegetation patterns along an altitudinal gradient of a top biodiversity hotspot. Biodivers. Conserv. 22:2767-2783.

Ejtehadi, H., Sepehri, A. and Akkafi, H.R. 2009. Methods of Measuring Biodiversity. - Ferdowsi Univ. of Mashhad Press, 226p. (In Persian)

Gaston, K.J. 2000. Global patterns in biodiversity. Nat. 405: 220-227.

Guo, Q., Kelt, D.A., Sun, Z., Liu, H., Hu, L., Ren, H. and Wen, J. 2013. Global variation in elevational diversity patterns. - Sci. Rep. 3: 1-7.

Hijmans, R.J., Cameron, S.E., Parra, J.L., Jones, P.G. and Jarvis, A. 2005. Very high resolution interpolated climate surfaces for global land areas. Int. J. of Climatol. 25: 1965-1978. (http://www.worldclim.org/version1)

Hill, M. 1973. Diversity and evenness: a unifying notation and its consequences. - Ecol. 54: 427-432.

Holdridge, L.R., Granke, W.C., Hatheway, W.H., Liang, T. and Tosi, Jr.J.A. 1971. Forest environments in tropical life zones: a pilot study. Pergamon, New York.

Hsieh, T.C., Ma, K.H. and Chao, A. 2016. Inext: Interpolation and Extrapolation for species diversity. $\mathrm{R}$ package version 2.0.12 Url: Http://Chao.Stat.Nthu.Edu.Tw/Blog/SoftwareDownload/.

Hua, Y. 2004. Distribution of plant species richness along elevation gradient in Hubei Province, China.
International Institute for Earth System Science, Nanjing University, Nanjing, China.

IRIMO, 2016. Analytical reports \& climatic data. I.R. of Iran Meteorological Organization. Available from: http://www.irimo.ir/ (accessed: 12 October 2016).

Lomolino, M.V. 2001. Elevation gradients of speciesdensity: historical and prospective views. - Glob. Ecol. Biogeogr. 10: 3-13.

MacArthur, R.H. 1965. Patterns of species diversity. Biol. Rev. 40: 510-533.

Magurran, A.E. 1988. Ecological Diversity and its Measurement. - Cambridge Univ. Press, 179 pp.

McCain, C.M. and Grytnes, J.A. 2010. Elevational Gradients in Species Richness. In: Encyclopedia of Life Sciences (ELS). - John Wiley \& Sons, Ltd: Chichester.

Morris, E.K., Caruso, T., Buscot, F., Fischer, M., Hancock, C., Maier, T.S., Meiners, T., Müller, C., Obermaier, E., Prati, D., Socher, S.A., Sonnemann, I., Wäschke, N., Wubet, T., Wurst, S. and Rillig, M.C. 2014. Choosing and using diversity indices: insights for ecological applications from the German Biodiversity Exploratories. - Ecol. And Evol. 4: 3514-3524.

Muñoz, M.E.S., De Giovanni, R., Siqueira, M.F., Sutton, T., Brewer, P., Pereira, R.S., Canhos, D.A.L. and Canhos, V.P. 2011. Openmodeller: a generic approach to species' potential distribution modelling. - GeoInforma. 15: 111-135.

Nogué, S., Rull, V. and Vegas-Vilarrúbia, T. 2013. Elevational gradients in the neotropical table mountains: patterns of endemism and implications for conservation. - Diversity Distrib. 19: 676-87.

R Core Team, 2016. R: A language and environment for statistical computing. R Foundation for Statistical Computing, Vienna, Austria. https://www.Rproject.org/.

Rahbek, C. 1997. The relationship among area, elevation, and regional species richness in Neotropical birds. - Am. Nat. 149: 875-902.

Rahbek, C. 2005. The role of spatial scale and the perception of large-scale species-richness patterns. Ecol. Lett. 8: 224-239.

Rapoport, E.H. 1982. Areography: geographical strategies of species. Trans. B. Drausal, vol. 1. Pergamon, New York.

Ribeiro, S., Fernandes, J.P. and Espírito-Santo, D.M. 2014. Diversity and floristic patterns of editerranean grasslands: the relative influence of environmental and land management factors. -Biodivers. Conserv. 23: 2903-2921.

Rohde, K. 1992. Latitudinal gradients in species diversity: the search for the primary cause. - Oikos. 65: 514-527.

Sánchez-González, A. and López-Mata, L. 2005. Plant species richness and diversity along an altitudinal gradient in the Sierra Nevada, Mexico. - Diversity Distrib. 11: 567-575.

Smith, M.A. 2015. Ants, elevation, phylogenetic diversity and community structure. - Ecosphere. 6: 117. 
Spehn, E.M. and Korner, Ch. 2010. Data mining for global trends in mountain biodiversity. - CRC Press Taylor \& Francis Group, United States of America.

Stevens, G.C. 1992. The elevational gradient in altitudinal range: an extension of rapoport's latitudinal rule to altitude. - The Am. Nat. 140: 893911

Subedi, S.C., Bhattarai, K.R. and Chauudhary, R.P. 2015. Distribution pattern of vascular plant species of mountains in Nepal and their fate against global warming. - J. Mt. Sci. 12: 1345-1354.

Underwood, E.C., Viers, J.H., Klausmeyer, K.R., Cox, R.L. and Shaw, M.R. 2009. Threats and biodiversity in the editerranean biome. - Divers. Distrib. 15: 188-197.

Vázquez, J.A.G. and Givnish, T.J. 1998. Altitudinal gradients in tropical forest composition, structure, and diversity in the Sierra de Manantán. - J. Ecol. 86: 999-1020.

Watkins, J.E.Jr., Cardelús, C., Colwell, R.K., and Moran, R.C. 2006. Species richness and distribution of ferns along an elevational gradient in Costa Rica. Am. J. Bot. 93: 73-83.

Whittaker, R.H. 1956. Vegetation of the Great Smoky Mountains. - Ecol. Monogr. 26: 1-80.
Whittaker, R.J., Willis, K.J. and Field, R. 2001. Scale and species richness: towards a general, hierarchical theory of species diversity. - J. Biogeogr. 28: 453470.

Willig, M.R., Kaufman, D.M. and Stevens, R.D. 2003. Latitudinal gradients of biodiversity: pattern, process, scale and synthesis. - Annu. Rev. Ecol. Evol. Syst. 34: 273-309.

Wilsey, B.J. and Potvin, C. 2000. Biodiversity and ecosystem functioning: importance of species evenness in an old field. - Ecol. 81: 887-892.

Zhang, D.-C., Zhang, Y.-H., Boufford, D.E. and Sun, H. 2009. Elevational patterns of species richness and endemism for some important taxa in the Hengduan Mountains, southwestern China. - Biodivers. Conserv. 18: 699-716.

$$
* * * * *
$$

How to cite this article:

Atashgahi, Z., Ejtehadi, H., Mesdaghi, M. and Ghassemzadeh, F. 2018. The existence of a unimodal or monotonic pattern in species richness and diversity along an elevational gradient: a case study in Heydari Wildlife Refuge, NE Iran - Nova Biol. Reperta 5 (3): 291-298. 